\title{
A review of Goodbye, ice: Arctic poems
}

\author{
by Lawrence Millman (2020) \\ Albuquerque, NM, USA: Coyote Arts. 83 pp. ISBN paper: 978-1-58775-031-1; e-book: 978-1-58775-032-8
}

Lawrence Millman, a mycologist, traveller and writer, describes his poetry collection Goodbye, ice as "a poetical account of [his] wanderings" (p. xi) over a period of 40 years. Beginning in Narsaq, West Greenland, the poems circle the Arctic world: Jan Mayen, Wrangel Island, Yukon, Nunavut. Such place names often serve instead of titles, and in sequence, the poems unify the territory across the spaces between pages. The poems themselves are verbal snapshots of things noticed or overheard on Millman's travels, and present with humour and an engaging directness the lived experience of a vital Arctic world, which is threatened by global industrialization and accelerating climate change.

The Arctic that Millman describes is not a sublime wilderness; his mycologist's eye is tuned to the small scale. Whilst the opening poem effectively sets a scene, which we might expect to see in a brochure advertising the Arctic wilderness as a tourist destination-cliffs, and an "iceberg-dotted sea/with white-capped mountains/rising in the distance" (p. 15)—-he lights the cliffs with sunburst lichen and draws our gaze to the hole at the top of a burial cairn, in which lies "a mossy skull/minus a jawbone/and a few random ribs" (p. 15). Here, the human is returned to the earth, peacefully, an accommodation with death that echoes throughout the collection. Subsequent poems pay close attention to the plants and creatures inhabiting this landscape- the lichen, moss and fungi, as well as the brighter flowers. Polar bears and dogs are given voices, and there is even a poem for mosquitoes, those "flying hypodermic needles" (p. 22), which remind Millman that he is part of the food chain, before he crushes them with his superior strength. Millman reflects in a poem written in response to Camsell Island, Nunavut, that true places are seldom on any map. The sense of place, which emerges from Goodbye, ice, is created out of a web of memories, stories and relationships, particulars of the land and of the various species that inhabit it, which transcends the boundaries of nation states.

\section{Correspondence}

E. Lewis Williams, Faculty of Literature, Drama and Creative Writing, University of East Anglia, Norwich Research Park, Norwich, NR4 7TJ, UK. E-mail: e.lewis-williams@uea.ac.uk

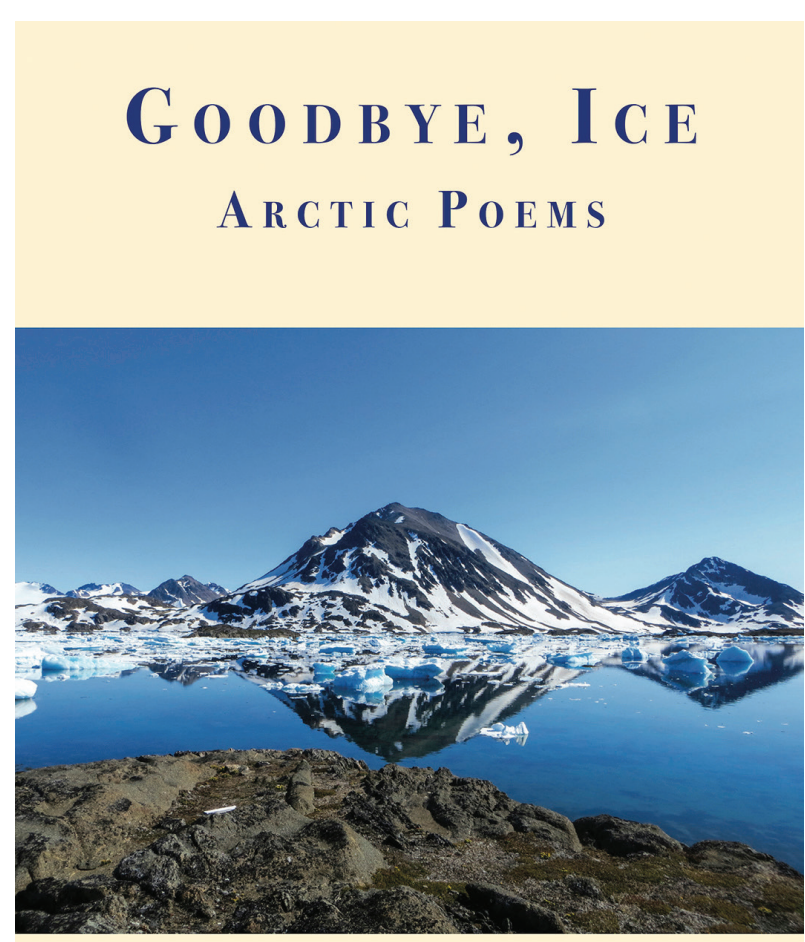

LA W R N CE M I L M A N

Walking the tundra
I don't need a GPS
for I can easily see
purple saxifrage and blue harebells
sedge meadows and fell fields
$\ldots$
all of which tell me where I am
and, indeed, who I am
(p. 75 )

The poems are elegiac in their impact; the title of the collection refers to the melting of ice that sustains a 
landscape and way of life. One of the final poems shows an Inuk man at a seal's breathing hole waiting for a seal to appear for one last time before the ice disappears. "Civilization" has travelled from the south bringing disease in the form of smallpox; there is a proliferation of litter, industrial and domestic- “even at the end of the world/there's no escaping human wipes" (p. 60). The collection ends with an epitaph, which restates the apparently wilful incapacity of people to act in the face of climate change. In this poem, homo sapiens reclines in a beach chair as the rising seas lap unnoticed at his feet. The message of Millman is clear. Our love for the earth should be like that of Diapensia lapponica-the circumboreal pincushion plant that marries "the earth's scoured bones" (p. 76), or like the glacial erratic_-"Pariah and bulwark, it offers a model of how to grasp the austere earth" (p. 30). If we do not, we will perish.

Human capacity for destruction is at the heart of Millman's stated preference for the world's flora and fauna over its people. Seeing the tusk of a woolly mammoth curving from a cutback by the Porcupine River, Millman gives the mammoth a voice to ask: "how could paltry creatures like you/have survived/and I did not?" (p. 39). Humans are weak (despite their impact), and vulnerable to falling rocks and the vast waves released by calving icebergs. They can be torn apart by polar bears or even rejected for their bizarre interests. "You're an advanced species/and this is what you do?" (p. 59) a polar bear asks the narrator, who is examining the contents of some excrement, before loping away. The poems are not an outright rejection of humanity; however; many are addressed to particular people, and these are often invisible guests inhabiting the poems alongside those who live in the far north. The indigenous people are written about with a respect for their close relationship with the natural world around them. Millman's knowledge of their stories, some of which were collected in his earlier book A kayak full of ghosts (2003), can be found in Goodbye ice. Several poems are versions of charms or anecdotes, identified as having been heard or sung in particular places. They help to create a sense of lives lived close to the land, where human beings communicate with what surrounds them, whether to charm an avalanche or to ask a lemming to reveal the location of the best berries. The hunter sings to the caribou about the beautiful mittens his wife will make with its skin, a man speaks to his kayak to hurry it home, and "The last shaman" celebrates a closeness to the landscape that could enable his song to "chant away/storms and wild winds/with the guttural of his voice" (p. 47). The poems echo the directness and episodic nature of traditional stories, as well as retelling some of them; however, they are very much written in Millman's voice.

Millman has strong opinions, and he is not afraid of offending his readers. The Christian God, creator of humankind, is presented as a rather ineffectual figure who struggles in a colder climate, missing baba ganoush and felafel. He is the Arctic raven's "grey-bearded inferior" (p. 20) and flies back to the Holy Land in a private jet. Tourists (in large groups) are bipeds who go on "photo feeding" frenzies (p. 36). There is farting and faecal matter. This is a book of poems to be enjoyed for its outspokenness, its take-me-as-you-find-me quality, its conversational tone and its encouragement, to see and appreciate the beauty in a world that, if nothing changes, will pass away.

\section{References}

Millman L. 2003. A kayak full of ghosts: Eskimo folk tales. Northampton, MA: Interlink Books. 